\title{
Perlindungan Hukum Terhadap Hutan Mangrove Pada Areal Pesisir Pantai
}

\section{Ricky Marthin Wattimena ${ }^{1 *}$, Wilshen Leatemia ${ }^{2}$, Lucia Charlota Octovina Tahamata $^{3}$}

${ }^{1}$ Fakultas Hukum PSDKU Universitas Pattimura, Aru, Indonesia

2,3Fakultas Hukum Universitas Pattimura, Ambon, Indonesia

@ : jermanricky691@gmail.com

: $X X X X X X X X X X X$

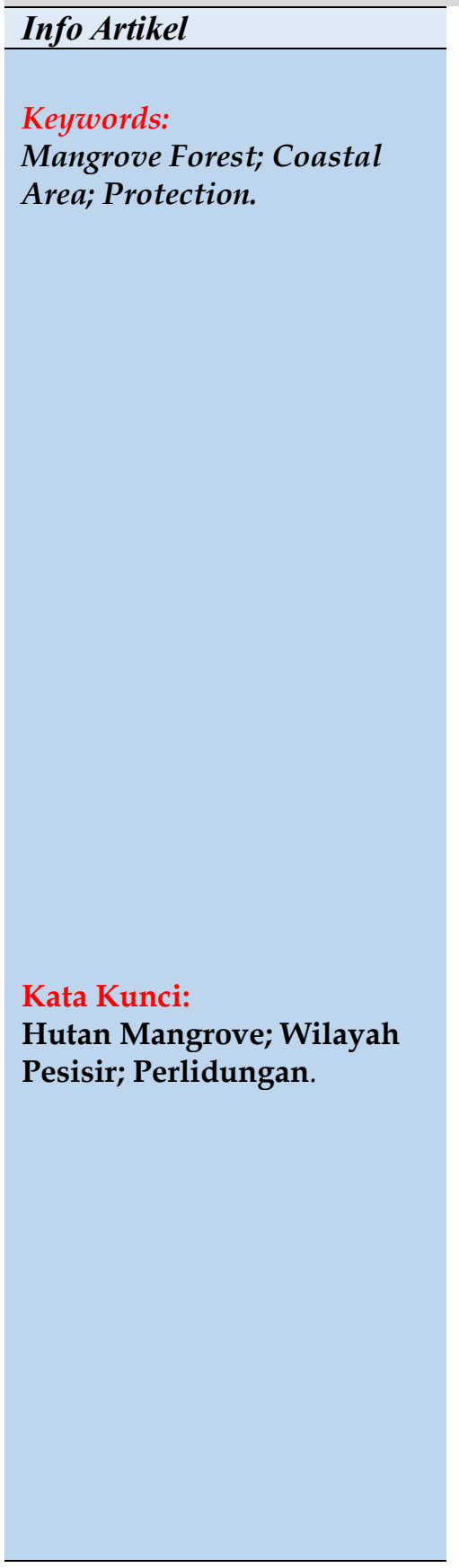

\begin{abstract}
Introductioan: One of the potentials of mangrove forests is to prevent coastal abrasion. With the existence of mangrove forests, erosion of coastal areas during the rainy season can be minimized. Besides that, mangroves can also be an ecosystem for crabs and various other types of fish. However, in the course of development, many times mangrove forests are converted and also destroyed because of development interests by individuals and development companies.

Purposes of the Research: The purpose of this article is to find out how to regulate the management of coastal areas and how to protect the law against mangrove forest areas on the coast of Piru Village, West Seram Regency.

Methods of the Research: This research is a normative research using a statutory approach with sources of legal materials used are primary legal materials, secondary legal materials and tertiary legal materials with qualitative analysis.

Results of the Research: The results of the study found that the regulation related to the management of coastal areas is regulated in Law No. 1 of 2014 and in its implementation in the field there is still damage to mangrove forests, especially in the coastal area of Piru Village, West Seram Regency and is detrimental to coastal communities because the coastal area is an area that should protected because it is important for the sustainability of the community in the area.
\end{abstract}


primer, bahan hukum sekunder dan bahan hukum tersier dengan analisis kualitatif.

Hasil Penelitian: Hasil penelitian ditemukan bahwa pengaturan terkait dengan pengelolaan wilayah pesisir diatur dalam UU No 1 Tahun 2014 dan dalam implemenasinya di lapangan masih adanya pengrusakan hutan mangrove terkhususnya pada kawasan pesisir pantai Desa Piru Kabupaten Seram Bagian Barat dan merugikan masyarakat pesisir karena wilayah pesisir tersebut merupakan daerah yang seharusnya dilindungi karena mempunyai penting bagi keberlangsungan masyarakat di daerah tersebut.

\section{A. PENDAHULUAN}

Lingkungan hidup sebagai kesatuan ruang dengan semua benda, daya, keadaan makhluk hidup termasuk manusia dan perilakunya begitu mempengaruhi alam itu sendiri. alam dapat di lihat sebagai Satu jalinan sistim kehidupan yang saling kaitmengait atau saling berhubungan satu dengan yang lainnya ${ }^{1}$. Pada pasal $28 \mathrm{H}$ Undangundang Dasar Negara Republik Indonesia Tahun 1945 telah di atur bahwa lingkungan hidup yang baik dan sehat merupakan hak asasi setiap warga negara Indonesia. Senyatanya kualitas lingkungan hidup yang semakin menurun telah mengancam kelangsungan perikihdupan manusia dan makhluk hidup lainnya, sehingga perl dilakukan perlindungan dan pengelolaan lingkungan hidup yang sungguh-sungguh dan konsisten oleh semua pemangku kepentingan. Terlebih berhadapan dnegan pemanasan global yang smeakin meningkat mengakibatkan perubahan iklim sehingga memperparah penurunan kualitas lingkungan hidup, karena itu perlu dilakukan perlindunga dan pengelolaan lingkungan hidup ${ }^{2}$. Masalah lingkungan hidup pada intinya adalah menemukan cara-cara yang harus dijalankan untuk menjamin dan menjadikan bumi dan alam sekitar sebagai ruang yang layak dihuni bagi kehidupan yang tentram, damai dan sejahtera. Karena itu tindakan yang mencemari lingkungan hidup sama artinya dengan mematikan hidup itu sendiri. ${ }^{3}$ Sejalan dengan pertumbuhan penduduk kebutuhan manusia terhadap sumberdaya alam secara otomatis juga bertambah yang dapat menyebabkan terjadinya penurunan atau kelangkaan sumberdaya di sebabkan oleh pertambahan penduduk. ${ }^{4}$

Perkembangan kebutuhan manusia selalu tergantung kepada persedian alam di mana manusia menjadi satu-satunya pengguna tertinggi dari alam, baik hasil alam yang ada di laut maupun hasil alam yang ada di darat. Salah satu kekayaan alam yang ada d darat yang paling banyak di buru oleh manusia adalah hutan. Hutan merupakan satu wilayah yang menjadi tempat tumbuhnya pohon-pohon dan jenis tanaman lain.

Hutan juga dapat di kategorikan sebagai ekosistem yang menjadi tempat hidup dan berinteraksi bagi hewan maupun tumbu-tumbuhan. Hutan terbagi menjadi tiga

${ }^{1}$ Muhamad Erwin, Hukum Lingkungan: Sistem Kebijaksanaan Lingkungan Hidup (Bandung: Refika Aditama, 2019), h. 23.

2 Ibid, h.23

3 Niniek Suparni, Pelestarian, Pengelolaan Dan Penegakan Hukum Lingkungan (Jakarta: Sinar Grafika, 1994), h. 28.

${ }^{4}$ Bruce Mitchell, B. Setiawan, and Dwita Hadi Rahmi, Pengelolaan Sumberdaya Dan Lingkungan (Yogyakarta: Gadjah Mada University Press, 2000), h. 10. 
bagian yakni bagian atas, bagian permukaan tanah dan bagian di bawah tanah. Di bagian atas hutan terdapat kanopi alami yakni dedaunan pohon yang tumbuh lembat. Di permukaan tanah hutan terdapat guguran daun- daun kering serta ditumbuhi semak- semak dan rerumhutan. Sedangkan di bagian bawah tanah hutan terdapat unsur hara, akar tanaman, sumber mata air dan juga dihuni mikro organisme.

Hutan terbagi juga atas beberapa macam jenis hutanHutan bisa ditemukan di wilayah dengan iklim tropis, dataran rendah dan juga dataran tinggi: Jenis Jenis Hutan berdasarkan iklim. Terdapat berbagai jenis hutan diantaranya adalah hutan gugur, hutan sabana, hutan heterogen, hutan homogen, hutan mangrove, hutan buatan dan hutan hujan tropis dan hutan mangrove. Indonesia sebagai negara yang berada di garis khatulistiwa mempunyai hutan hujan tropis yang selalu lembab sepanjang tahun. Keanekaragaman hayati yang berada di dalam hutan hujan tropis sangatlah tinggi. Hal ini menjadi potensi sumber daya alam tersendiri bagi Indonesia selain hutan hujan tropis juga terdapat hutan mangrove yang tumbuh di daerah pesisir pantai.

Salah satu potensi hutan mangrove adalah sebagai pencegah abrasi pantai. Dengan adanya hutan mangrove maka pengikisan areal pantai pada saat musim penghujan dapat di minimalisir selain itu mangrove juga dapat menjadi ekosistem bagi kepiting dan berbagai jenis ikan lainnya. Namun dalam perkembangan pembangunan, banyak kali hutan mangrove di alih fungsikan dan juga di hancurkan karena kepentingan pembangunan oleh orang perorangan maupun perusahan pengembang.

Hal ini pun terjadi pada Desa Piru Kabupaten Seram Bagian Barat, di mana sepanjang pantai pada pesisir dusun waihatu desa piru Seram Bagian Barat, ekosistem mangrove di hancurkan oleh pihak-pihak yang tidak bertanggung jawab untuk mengejar keuntungn pribadi padahal di dalam Undang-undang pengelolaan pesisir Hutan mangrove di lindungi.

Fakta inilah yang mendorong peneliti untuk melakukan penelitian terkait dengan Bagaimana pengaturan pemanfaatan wilayah pesisir berdasarkan Undangundang dan Bagaimana perlindungan hukum terhadap wilayah pesisir Dusun Waihatu Desa Piru Kabupaten Seram Bagian Barat.

\section{B. METODE PENELITIAN}

Penelitian ini merupakan Penelitian Normatif dengan menggunakan pendekatan perundang-undangan dengan sumber bahan hukum yang di gunakan adalah bahan hukum primer, bahan hukum sekunder dan bahan hukum tersier dengan analisis kwalitatif.

\section{HASIL DAN PEMBAHASAN}

Pembangunan tidak hanya mendatangkan sejumlah dampak positif (manfaat) bagi kelangsungan kehidupan manusia dan lingkungan hidup tetapi dalam waktu yang bersamaan juga sekaligus dapat mendatangkan sejumlah ancaman bagi 
kelangsungan kehidupan manusia dan lingkungan hidup. ${ }^{5}$ Bahaya yang senantiasa yang mengancam kelestarian lingkungan dari waktu ke waktu ialah pencemaran dan perusakan lingkungan. Ekosistem dari suatu lingkungan dapat terganggu kelestariannya oleh karena pencemaran dan perusakan lingkungan hidup. Istilah pencemaran dan pengrusakan lingkungan hidup tesebut seringkali di campuradukan padahal di antara keduannya memiliki realitas sendiri-sendiri sebagai berikut:

1) Pencemaran adalah suatu keadaan dalam mana suatu zat atau energy diintroduksikan ke dalam suatu lingkungan oleh kegiatan manusia atau oleh proses alam sendiri dalam konsentrasi sedemikian rupa, hingga menyebabkan terjadinya perubahan dalam keadaan termaksud yang mengakibatkan lingkungan itu tidak berfungsi seperti semula dalam arti kesehatan, kesejahteraan, dan keselamatan hayati. ${ }^{6}$

2) Perusakan lingkungan adalah tindakan orang yang menimbukan perubahan langsung dan tidak langsung terhadap sifat fisik, kimia, hayati lingkungan hidup sehingga melampaui kriteria baku kerusakan lingkungan hidup. ${ }^{7}$

Perkembangannya istilah "pencemaran lingkungan" mengalami kekhususan sebagaimana berikut: pencemaran air, pencemaran daratan, pencemaran laut, pencemaran udara, pencemaran angkasa, pencemaran pandangan, pencemaran rasa pencemaran kebudayaan.

Pencemaan lingkungan menimbulkan kerugian yang dapat terjadi dalam bentuk:

1) Kerugian ekonomi dan sosial

2) Gangguan kesehatan

Sementara menurut golongannya pencemaran itu dapat di bagi atas:

1) Kronis di mana kerusakan terjadi secara progresif tetapi lambat

2) Kejutan (akut) kerusakan mendadak dan berat biasanya timbul dari kecelakaan

3) Berbahaya dengan kondisi biologis berat dan dalam hal ada radioaktif terjadi kerusakan genetis dan

4) Katastrofis di sini kematian organisme hidup banyak dan mungkin organisme ini punah.

Selain itu kerusakan lingkungan dapat juga di artikan sebagai proses penurunan atau kemunduran mutu lingkungan. Penurunan atau kemunduran mutu lingkuangan ini di tandai dengan hilangnya sumberdaya tanah, air, udara, punahnya flora dan fauna liar serta kerusakan ekosistem. Penyebab kerusakan lingkungan dapat di bagi menjadi dua faktor:

1) Akibat peristiwa alam

Banjir, abrasi, letusan gunung berapi, putting beliung, gempa bumi dan tsunami merupakan beberapa contoh bencana alam. Bencana-bencana inilah yang menjadi penyebab rusaknya lingkungan hidup akibat peristiwa alam 150-152.

${ }_{5}^{5}$ Otto Soemarwoto, Ekologi, Lingkungan Hidup DanPembangunan (Jakarta: Djambatan, 1994), h.

${ }^{6}$ Erwin, Hukum Lingkungan: Sistem Kebijaksanaan Lingkungan Hidup. Op. Cit. h. 28.

7 Undang-Undang Nomor 32 Tahun 2009 
tetapi bila di teliti bencana-bencana seperti ini bisa juga terjadi akibat ulah manusia.

2) Akibat ulah manusia

Kerusakan akibat ulah manusia justru lebih besar dari bencana alam mengingat kerusakan yang terjadi dapat berlangsung secara terus menerus dan cenderung meningkat, kerusakan ini umumnya terjadi akibat ulah dari manusia yang tidak ramah dengan lingkungan. Seperti pencemaran tanah, alih fungsi hutan dan pengrusakan hutan.

Kasus yang terjadi di Desa Piru kabupaten seram bagian barat di mana tanpa sepengetahuan Pemerintah Kabupaten Seram Bagian Barat dan juga Pemerintah Desa Piru areal pesisir pantai dari Dusun Hatu di hancurkan oleh salah satu perusahaan yang berdiam di sana dengan cara melakukan pembabatan kawasan hutan mangrove di areal pantai dusun hatu dengan alasan yang tidak jelas. Sejak tahun 2018 perusahan membeli tanah pada areal dusun hatu seluas 3,4 HA kemudian tanah pada areal ini di ratakan. Akan tetapi areal mangrove yang sudah berada pada kawasan perairan pantai pada dusun hatu ini juga termasuk di ratakan bukan hanya itu sisa pohon mangrove yang sudah di tebang pun di cungkil hingga ke akar sehingga mengakibatkan mangrove sudah tidak dapat tumbuh kembali dengan maksimal pada areal ini. Akibat lain dari penggusuran ini yaitu rusaknya habitat kepiting bakau dan ikan jenis mangrove jeack yang biasanya menjadikan akar-akar bakau sebagai tempat bertelur dan berlindung

Wilayah pesisir merupakan daerah peralihan laut dan daratan. Kondisi tersebut menyebabkan wilayah pesisir mendapatkan tekanan dari berbagai aktivitas dan fenomena di darat maupun di laut. Fenomena yang terjadi di daratan antara lain abrasi, banjir dan aktivitas yang dilakukan oleh masyarakat yaitu pembangunan permukiman, pembabatan hutan untuk persawahan, pembangunan tambak dan sebagai yang pada akhirnya memberi dampak pada ekosistem pantai. 8 Perairan pesisir merupakan wilayah sangat produktif. Namun di balik potensi tersebut sering munculnya masalah yaitu dambak negatif bagi potensi sumberdaya alam bahari akibat adanya pembangunan. Aktifitas manusia dalam pemanfaatan sumberdaya alam di atasnya seperti pertanian, petambangan, navigasi, pariwisata serta pembangunan yang seringkali menjadi masalah sehingga manfaat dan nilai guna ekosistem menjadi menurun. Sebagai negara hukum pelaksanaan sistem pengembangan wilayah pesisir dan laut sebagai bagian dari sistem pembangunan yang berkelanjutan harus sesuai dengan norma dan di beri dasar hukum yang jelas, tegas dan menyeluruh guna menjamin kepastian hukum bagi upaya pengelolaan wilayah pesisir. Selain itu, Cobb (1992) juga ber-pendapat bahwa untuk menyeimbang-kan kepentingan ekonomi dan kepentin-gan ekologis maka seharusnya ditengahi oleh pembentukan kebijakan pemerintah yang tertuang dalam suatu dokumen kebijakan ${ }^{9}$. Berangkat dari hal tersebut, peranan hukum dan dokumendokumen kebijakan merupakan suatu hal yang penting untuk mengakomodir arah kebi-jakan pembangunan yang berlandaskan konsep keadilan lingkungan.

8 Hastuti, "Wilayah Pesisir Dan Fenomena-Fenomena Yang Terjadi Di Pantai" (Universitas Hassanudin, 2012).

9 John B Cobb, Sustainability: Economics, Ecology, and Justice (New York: Orbis Books, 1992), h. 58. 
Pasal 33 ayat 3 Undang-undang 1945 menyebutkan bahwa bumi air dan kekayaan alam yang terkandung di dalamnya adalah karunia Tuhan yang maha Esa dan di kuasai oleh negara untuk sebesar-besarnya kemakmuran rakyat. Pasal ini bermaksud bahwa pendayagunaan kekayaan alam di maksudkan untuk sebesarbesarnya kemakmuran rakyat dengan tetap memperhatikan kelestarian dan keseimbangan lingkungan hidup, pembangunan berkelanjutan kepentingan ekonomi dan budaya masyarakat lokal setempat, serta penataan ruang yang pengusahaannya di atur lewat ketentuan perundang-undangan.

Undang-Undang Nomor 27 Tahun 2007 tentang PWK-PK dalam pasal tiga tentang asas dan tujuan menyatakan bahwa pengelolaan wilayah pesisir dan pulaupilau kecil harus berasaskan

1) Keberlangsungan

2) Kepastian hukum

3) Kemitraan

4) Pemerataan

5) Peran serta masyarakat

6) Keterbukaan

7) Desentralisasi

8) Keadilan

9) Konsistensi

10) Keterpaduan

11) keberlanjutan

Asas keberlanjutan diterapkan agar:

1) pemanfaatan sumber daya tidak melebihi kemampuan regenerasi sumber daya hayati atau laju inovasi substitusi sumber daya nonhayati pesisir

2) pemanfaatan Sumber Daya Pesisir saat ini tidak boleh mengorbankan (kualitas dan kuantitas) kebutuhan generasi yang akan datang atas sumber daya pesisir; dan

3) pemanfaatan sumber daya yang belum diketahui dampaknya harus dilakukan secara hati-hati dan didukung oleh penelitian ilmiah yang memadai.

Asas kepastian hukum diperlukan untuk menjamin kepastian hukum yang mengatur pengelolaan sumber daya pesisir dan pulau-pulau kecil secara jelas dan dapat dimengerti dan ditaati oleh semua pemangku kepentingan; serta keputusan yang dibuat berdasarkan mekanisme atau cara yang dapat dipertanggungjawabkan dan tidak memarjinalkan masyarakat pesisir dan pulau-pulau kecil. Asas kemitraan merupakan kesepakatan kerja sama antarpihak yang berkepentingan berkaitan dengan Pengelolaan Wilayah Pesisir dan Pulau-Pulau Kecil. Asas pemerataan ditujukan pada manfaat ekonomi sumber daya pesisir dan pulau-pulau kecil yang dapat dinikmati oleh sebagian besar anggota masyarakat.

Asas peran serta masyarakat dimaksudkan:

1) agar masyarakat pesisir dan pulau-pulau kecil mempunyai peran dalam perencanaan, pelaksanaan, sampai tahap pengawasan dan pengendalian; 
2) memiliki informasi yang terbuka untuk mengetahui kebijaksanaan pemerintah dan mempunyai akses yang cukup untuk memanfaatkan sumber daya pesisir dan pulaupulau kecil

3) menjamin adanya representasi suara masyarakat dalam keputusan tersebut

4) memanfaatkan sumber daya tersebut secara adil.

Asas Keterbukaan dimaksudkan adanya keterbukaan bagi masyarakat untuk memperoleh informasi yang benar, jujur, dan tidak diskriminatif tentang Pengelolaan Wilayah Pesisir dan Pulau-Pulau Kecil, dari tahap perencanan, pemanfaatan, pengendalian, sampai tahap pengawasan dengan tetap memperhatikan perlindungan atas hak asasi pribadi, golongan dan rahasia negara. Asas Desentralisasi merupakan penyerahan wewenang pemerintahan dari Pemerintah kepada Pemerintah Daerah otonom untuk mengatur dan mengurus urusan pemerintahan di bidang Pengelolaan Wilayah Pesisir dan Pulau-Pulau Kecil. Asas Keadilan merupakan asas yang berpegang pada kebenaran, tidak berat sebelah, tidak memihak, dan tidak sewenangwenang dalam pemanfaatan sumber daya pesisir dan pulau-pulau kecil. Asas Konsistensi merupakan konsistensi dari berbagai instansi dan lapisan pemerintahan, dari proses perencanaan, pelaksanaan, pengendalian, dan pengawasan untuk melaksanakan program Pengelolaan Wilayah Pesisir dan PulauPulau Kecil yang telah diakreditasi.

Asas Keterpaduan dikembangkan dengan:

1) mengintegrasikan kebijakan dengan perencanaan berbagai sektor pemerintahan secara horizontal dan secara vertikal antara pemerintah dan pemerintah daerah;dan

2) mengintegrasikan ekosistem darat dengan ekosistem laut berdasarkan masukan perkembangan ilmu pengetahuan dan teknologi untuk membantu proses pengambilan putusan dalam Pengelolaan Wilayah Pesisir dan PulauPulau Kecil.

Asas Keberlanjutan diterapkan agar:

1) pemanfaatan sumber daya tidak melebihi kemampuan regenerasi sumber daya hayati atau laju inovasi substitusi sumber daya nonhayati pesisir;

2) pemanfaatan Sumber Daya Pesisir saat ini tidak boleh mengorbankan (kualitas dan kuantitas) kebutuhan generasi yang akan datang atas sumber daya pesisir; dan

3) pemanfaatan sumber daya yang belum diketahui dampaknya harus dilakukan secara hati-hati dan didukung oleh penelitian ilmiah yang memadai.

Undang-undang Nomor 1 Tahun 2014 Tentang Perubahan Atas Undang Undang Tahun 2007 Tentang Pengelolaan Wilayah Pesisir dan Pulau - Pulau Kecil. UU Nomor 1 Tahun 2014 menegaskan bahwa Pengelolaan Wilayah Pesisir dan Pulau - Pulau Kecil adalah suatu pengoordinasian perencanaan, pemanfaatan, pengawasan, dan pengendalian sumber daya pesisir dan pulau-pulau kecil yang dilakukan oleh Pemerintah dan Pemerintah Daerah, antarsektor, antara ekosistem darat dan laut, serta antara ilmu pengetahuan dan manajemen untuk meningkatkan kesejahteraan rakyat dengan demikian di butuhkan keterlibatan dan kordinasi lintas 
sector untuk mengawal proses pengelolaan wiyah pesisir terutama yang berada pada wilayah-pulau-pulau kecil. Undang-undang No 23 tahun 2014 tentang Otonomi Daerah di mana izin pengelolaan wilayah pesisir berada di tangan Pemerintah Provinsi sedangkan tahun 2014 tentang pengelolaan pesisir dan Pulau-pulau Kecil izin Pengelolaan wilayah pesisir dapat di lakukan oleh Pemerintah Daerah.

Agenda 21 indonesia, dalam agenda ini Indonesi telah menerima agenda 21 global sebagai persetujuan tidak mengikat hasil konverensi unced 1992 dan menjadikannya pedoman dasar bagi penyelenggaraan dan penyusunan kebijakan lingkungan dan pembangunan. Ketentuan bab 18 dalam agenda 21 indonesia tentang pengelolaan wilayah pesisir menjadi sangat penting karena kondisi lingkungan perairan wilayah laut membutuhkan penanganan khusus. Penanganan khusus pada wilayah laut meliputi aspek keterpaduan dan kewenangan kelembagaan sehingga di harapkan sumberdaya yang berada di kawasan ini dapat menjadi produk unggulan dalam pembangunan bangsa

Deklarasi Bunaken 1998 oleh presiden B.J. Habibi Deklarasi ini merupakan salah satu tonggak pembangunan kelautan Indonesia dan merupakan upaya kembali untuk memanfaatkan laut setelah pembangunan pada era sebelumnya lebih berfokus pada daratan. Deklarasi ini terbentuk dengan harapan bahwa ada perhatian dari pemerintah dan masyarakat terhadap pengembangan pemenfaatan dan pemeliharaan perkembangan kelautan di indonesia. Sebagai negara hukum pelaksanaan sistem pengembangan wilayah pesisir dan laut sebagai bagian dari sistem pembangunan yang berkelanjutan harus sesuai dengan norma dan di beri dasar hukum yang jelas, tegas dan menyeluruh guna menjamin kepastian hukum bagi upaya pengelolaan wilayah pesisir

Terkait dengan pengrusakan hutan mangrove di pesisir dusun hatu desa piru kabupaten Seram bagian barat penulis berpendapat bahwa tindakan destruktif terjadi karena ketidaktahuan dan ketidaksadaran bahwa kegiatan yang di lakukan mengancam kesinambungan sumberdaya pesisir dan lautan, rendahnya kesadaran atau ketidaktahuan bahwa kegiatan yang bersifat destruktif akan mengancam keseimbangan sumberdaya alam yang menjadi pemicu kerusakan lingkungan seperti hutan mangrove. Dalam pengelolaan hutan mangrove pada wilayah pesisir pantai desa piru masyarakat desa memiliki kewenangan untuk berpartisipasi baik dalam pengendalian maupun dalam hal pengawasan dengan cara dapat menyampaikan laporan kepada pihak berwajib setiap kejadian yang berpotensi dapat mengancam keberlangsungan ekosistem mangrove pada pesisir desa. Salah satu cara yang perlu dilakukan mengajak seluruh pihak termasuk masyarakat untuk bersama-sama menjaga lingkungan pesisir. Langkah pemberdayaan masyarakat guna memunculkan kesadaran perlu diberikan karena akan menjamin terciptanya pengelolaan lingkungan yang lebih efektif dan berkelanjutan. ${ }^{10}$

Selain itu peran serta Pemerintah Daerah bersama semua elemen masyarakat menjadi hal yang penting seperti tergambar dalam Undang-undang nomor 27 tahun

10 Herry Fitriansah, "Keberlanjutan Pengelolaan Lingkungan Pesisir Melalui Pemberdayaan Masyarakat Di Desa Kwala Lama Kabupaten Serdang Bedagai," Jurnal Pembangunan Wilayah Dan Kota 8, no. 4 (2012): 360-70, https:/ / doi.org/10.14710/pwk.v8i4.6492.

116 B A L OB E Law Journal Vol. 1 No. 2, Oktober 2021 
2007 Jo Undang-undang nomor 1 tahun 2014 tentang pengelolaan wilayah pesisir dan pulau-pulau kecil di mana untuk menjamin terselenggaranya pengelolaan pesisir dan pulau-pulau kecil secara terpadu dan berkelanjutan, di lakukan pengawasan dan/atau pengendalian terhadap pelaksanaan ketentuan di bidang pengelolaan wilayah pesisir dan pulau-pulau kecil oleh pejabat tertentu yang berwenang di bidang pengelolaan wilayah pesisir dan pulau-pulau kecil sesuai dengan sifat pekerjaannya dan di beri wewenang kepolisian khusus. Selain itu pengawasan dan atau pengendalian di atas di lakukan oleh pejabat pegawai negeri sipil tertentu yang menangani bidang pengelolaan wilayah pesisir dan pulau-pulau kecil sesuai sifat pekerjaan yang di milikinya.

Pejabat pegawai negeri tertentu sebagai mana di maksud diatas berwenang untuk:

1) Mengadakan patroli/perondaan di wilayah pesisir dan pulau-pulau kecil atau wilayah hukumnya serta

2) Menerima laporan yang menyangkut perusakan ekosistem pesisir, kawasan konservasi, kawasan pemanfaatan umum dan kawasan strategis nasional lainnya.

Kewenangan pejabat di atas di atur dengan peraturan Menteri. Selain itu juga dalam rangka pelaksanaan dan pengendalian pengelolaan pulau-pulau kecil pemerintah dan pemerintah daerah wajib melakukan pemantauan, pengematan lapangan dan atau evaluasi terhadap perencanaan pelaksanaannya. Lingkungan hidup yang terganggu keseimbangannya perlu di kembalikan fungsinya sebagai kehidupan dan memberi manfaat bagi kesejateraan masyarakat dan keadilan antar generasi dengan cara meningkatkan penegakan dan perlindungan hukum. ${ }^{11}$ Pengaturan lingkungan secara hukum dapat menjamin kepastian dan ketertiban dalam pengelolaan lingkungan untuk mewujutkan keadilan, karena hukum memiliki sanksi untuk memaksakan kehendaknya jika perlu. Dalam pada itu, posisi dan peran hukum dalam pengelolaan lingkungan sebagai sarana ${ }^{12}$. Sebagai sarana keampuhan dan kedayagunaan hukum akan selalu bergantung kepada siapa dan dengan cara bagaimana di gunakannya. Betapapun ampuh dan sempurnanya suatu sarana, namun jika yang menggunakannya tidak dapat mentaati maka tujuan dari hukum yaitu keadilan akan sulit untuk dipenuhi.

\section{P E N U T U P}

Terkait dengan pengrusakan hutan mangrove di pesisir Dusun Hatu Desa Piru Kabupaten Seram Bagian Barat ditemukan bahwa tindakan destruktif terjadi karena ketidaktahuan dan ketidaksadaran dari pelaku-pelaku yang tidak bertanggungjawab bahwa kegiatan yang di lakukan mengancam kesinambungan sumberdaya kawasan pesisir dan lautan Desa Piru, rendahnya kesadaran atau ketidaktahuan bahwa kegiatan yang bersifat destruktif akan mengancam keseimbangan sumberdaya alam yang menjadi pemicu kerusakan lingkungan seperti hutan mangrove.

\footnotetext{
11 Erwin, Hukum Lingkungan: Sistem Kebijaksanaan Lingkungan Hidup. Op. Cit.

12 Munadjat Danu Saputra, Hukum Lingkungan (Jakarta: Bina Cipta, 1981).
} 


\section{REFERENSI}

Cobb, John B. Sustainability: Economics, Ecology, and Justice. New York: Orbis Books, 1992.

Erwin, Muhamad. Hukum Lingkungan: Sistem Kebijaksanaan Lingkungan Hidup. Bandung: Refika Aditama, 2019.

Fitriansah, Herry. "Keberlanjutan Pengelolaan Lingkungan Pesisir Melalui Pemberdayaan Masyarakat Di Desa Kwala Lama Kabupaten Serdang Bedagai." Jurnal Pembangunan Wilayah Dan Kota 8, no. 4 (2012): 360-70. https://doi.org/10.14710/pwk.v8i4.6492.

Hastuti. "Wilayah Pesisir Dan Fenomena-Fenomena Yang Terjadi Di Pantai." Universitas Hassanudin, 2012.

Mitchell, Bruce, B. Setiawan, and Dwita Hadi Rahmi. Pengelolaan Sumberdaya Dan Lingkungan. Yogyakarta: Gadjah Mada University Press, 2000.

Saputra, Munadjat Danu. Hukum Lingkungan. Jakarta: Bina Cipta, 1981.

Soemarwoto, Otto. Ekologi, Lingkungan Hidup DanPembangunan. Jakarta: Djambatan, 1994.

Suparni, Niniek. Pelestarian, Pengelolaan Dan Penegakan Hukum Lingkungan. Jakarta: Sinar Grafika, 1994. 